\title{
Videothoracoscopic sympathectomy - a standard treatment for primary hyperhidrosis at the Clinic of Thoracic Surgery in Sremska Kamenica
} \author{
Dejan ILINČIĆ, Miroslav ILIĆ \\ Clinic of Thoracic Surgery, Institute for Pulmonary Diseases of Vojvodina, Sremska Kamenica, \\ Univeristy of Novi Sad, Serbia \\ *Correspondence: Ivan Kuhajda, E mail: kuhajda@gmail.com
}

Ivan KUHAJDA*, Miloš KOLEDIN, Dejan ĐURIĆ, Milorad BIJELOVIĆ, Mišel MILOŠEVIĆ,

UDC 616.56-008.8-089.87

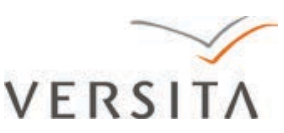

\begin{abstract}
Primary hyperhidrosis affects approximately $3 \%$ of the world's population, particularly young female adults. It is defined as excessive, profuse sweating of the palms, soles, armpits and face. Conservative treament includes diverse modalities, however, surgical treatment has shown the best long-term results. The objective of this study was to assess some disease-specific epidemiological characteristics in a pre-selected group of patients seeking surgical therapy, as well as outcomes of thoracoscopic sympathectomy. The severity and impact of hypehidrosis was assessed, using Hyperhidrosis Disease Severity Scale (HDSS: patients rate the serverity of symptoms on a scale from 1 to 4 ). Thoracoscopic sympathectomy was performed using a double lumen endotracheal tube, via bilateral $5 \mathrm{~mm}$ dual port videothoracoscopic camera $0^{\circ}$, and an endoscopic ultrasound activated harmonic scalpel. The sympathetic chain was resected on both sides at the level of the second and the third thoracic ganglion (T2 and T3), using an ultrasound knife. The extirpated chain was also at the level T3-T4 and sent for ex tempore analysis. There were 162 patients undergoing thoracoscopic sympathectomy: $39.51 \%$ were males and $60.49 \%$ females; at presentation their mean age $( \pm$ SD) was $30.5( \pm 8.3)$, range $16-58$ years. Axillary hyperhidrosis occurs later than palmar-axillary-plantar $(p<0.05)$. A total of $35.18 \%$ of the evaluated patients were able to name at least one member of their families who also suffered from hyperhidrosis. The most commonly affected area was palmar-axillary-plantar (30.25\%). Fifty patients $(30.86 \%)$ received conservative therapy before surgery. The most commonly used conservative therapy modalities included different kinds of ointments/tinctures (11.73\%), botox (8.02\%) and iontophoresis (2.47\%). Prior to surgery, $91.36 \%$ of patients reported severe sweating (HDSS score 3 or 4). The highest mean score was given for a combination of facial-palmar-axillaryplantar hyperhidrosis $(3.80 \pm 0.24)$. All surgeries were successfully performed, with no complications, or perioperative morbidity. The mean hospital stay was $1.28 \pm 0.68$ days long. After surgery, $93.21 \%$ of patients reported mild or moderate hyperhidrosis (HDSS score 1 or 2). Compensatory sweating (lower part of the back, and abdomen) was reported by $34.57 \%$ of patients after the surgery. All patients had a 6-months long follow-up: a significant improvement in quality of life was reported by $84.56 \%$ of patients (Yates corrected $\left.\chi^{2}(1)=228.42 ; p=0.0000\right)$ ); due to compensatory sweating, only $4.94 \%$ and $1.85 \%$ of patients reported bad and very bad quality of life, respectively.

In conclusion, nowadays videothoracoscopic sympathectomy is a standard treatment for primary hyperhidrosis with a high success rate.
\end{abstract}

\section{Key words}

Hyperhidrosis; Sympathectomy; Thoracic Surgery, Video-Assisted

$\mathrm{T}$ he sympathetic nervous system is a part of the autonomic nervous system which stimulates sweat production. Sympathetic innervations to upper extremities are at the level of the second and the third thoracic ganglion (T2 and T3), to armpits at T4 and
T5, and to lower limbs at T2 and T7.

Excessive sweating or hyperhidrosis affects approximately $3 \%$ of the world population $(1,2)$, predominantly young female adults $(3,4)$. It is defined as excessive bilateral, mostly symmetrical sweating 
pattern that does not correlate with local environment or physical activities, but results in profuse sweating of the palms, feet, armpits or face.

Hyperhidrosis may be classified as primary hyperhidrosis (idiopathic) with obscure etiology, and secondary hyperhidrosis due to certain diseases such as diabetes mellitus, endocrine disorders (e.g., hyperthyroidism), secretory tumors (pheochromocytoma, carcinoid tumors, pituitary gland tumors), tuberculosis, lymphomas, certain neurological, psychiatric, or sympathetic nervous system disorders (5).

Moreover, according to anatomic distribution, hyperhidrosis may be classified as focal and generalized. Primary or idiopathic hyperhidrosis is typically focal and limited to the armpits, palms, soles or craniofacial area. The diagnosis of primary hyperhidrosis is often based on patient's symptoms, medical history of excessive sweating, and specific clinical findings. The intensity of hyperhidrosis has not yet been precisely graded, but it may be mild, moderate and intense. Some authors have proposed the gravimetric method to precisely measure the sweat quantity by means of weighing the sweat-soaked paper, but this method is still reserved only for laboratory studies (6).

There also appears to be a genetic predisposition to primary hyperhidrosis, since $30 \%$ to $65 \%$ of patients report positive family history. An autosomal dominant mode of transmission with incomplete disease penetrance was reported (7).

Unlike functional sweating, which is due to physical exercise, fatigue or fever, primary hyperhidrosis develops as a consequence of either emotional problems or anxiety. Patients with primary hyperhidrosis have serious social problems which disturb their normal social communication. Various methods for reducing excessive sweating include: special diets (without coffee, tea, coca-cola, chocolate), diverse antiperspirants, such as over-the counter ointments/tinctures, topical aluminium chloride, medicines, drugs (oral anticholinergics), tap water ionophoresis (9), intradermal injections of botulinum toxin type A (botox) (10,11), but only surgical treatment has shown the best long-term results (12-14).

The objective of this study was to assess diseasespecific epidemiological characteristics of primary focal hyperhidrosis, in preselected patients seeking surgical help, as well as outcomes of thoracoscopic sympathectomy.

\section{Material and methods}

Between January 2008 and December 2009, 162 patients with primary hyperhidrosis were evaluated at the Clinic of Thoracic Surgery, Institute for Pulmonary Diseases of Vojvodina, Sremska Kamenica, Serbia, before and after thoracoscopic sympathectomy. All patients had a several-year history of excessive sweating, unresponsive to conservative treatment regimens (diet, antiperspirants, medicines, drugs).

\section{Surgical technique}

All surgeries were performed in total endotracheal anesthesia using a double lumen endotracheal tube. The patients were put into lateral decubitus position, with a rolled pillow under the top of scapula, in order to additionally extend the intercostal spaces (Figure 1). The intraoperative monitoring included: arterial blood pressure, electrocardiography, and pulse oximetry. With the lung on the operative side collapsed, the following instruments were introduced into pleural space via bilateral $5 \mathrm{~mm}$ dual port approach (Aesculap, Tuttlingen, Germany): a videothoracoscopic camera (Telescope Aesculap 5 $\mathrm{mm} 0^{\circ}$, Tuttlingen, Germany) which was connected with the video data processing system (Richard Wolf 3CCD Camera System, Tuttlingen, Germany), Aesculap grasper and an ultrasonic surgical scalpel

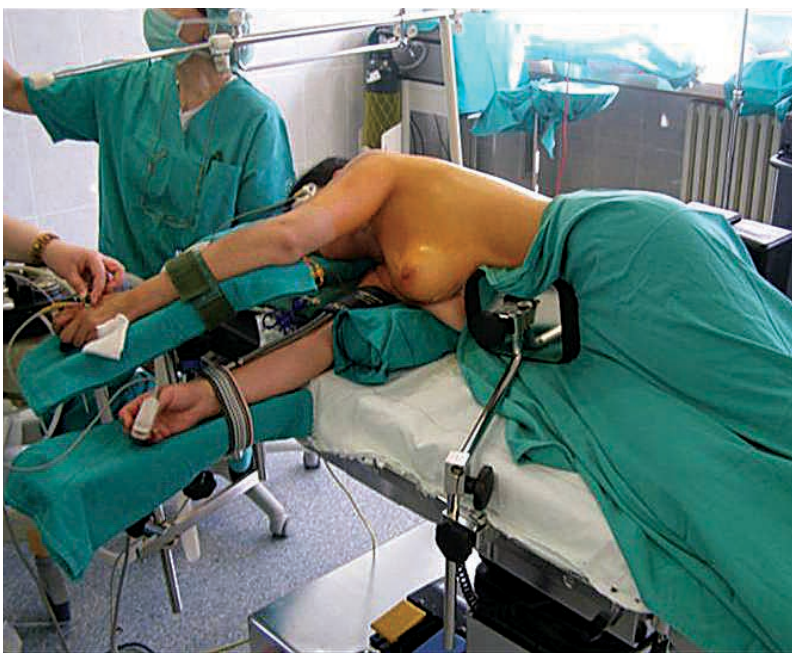

Figure 1. The patient is put into a lateral decubitus position 
(Auto Sonix-Hook Probe; Auto Sonix-Ultrasonic Surgical System Tyco, International Health Care). After identification of the first rib and the sympathetic chain, the chain was cut with an ultrasonic scalpel on both sides between T2 and T3, and the 4th chain was extirpated at the level T3-T4 (Figure 2) and sent for histopathological examination ex tempore. The parietal pleura was resected along the body of the second and the third rib with ultrasonic scissors, starting from the costovertebral angle, in order to destroy the Kuntz fibers. The surgery ended by introducing a single thoracic drain No 16F connected to the active suction of $-20 \mathrm{cmH} 2 \mathrm{O}$. The drain was fixed by Sofsik 0 (Тусо) and the skin suture performed by Dafilon 3.0 (B. Braun) and Vicryl 3.0 (Ethicon). The same surgical procedure was performed on the opposite side as well. After radiological verification of pulmonary parenchyma re-expansion, drains were removed two hours after surgery.

Exclusion criteria for surgery: former thoracic surgery, serious cardiac circulation or pulmonary insufficiency, pleural empyema. Exclusion criteria also included: patients suffering from secondary hyperhidrosis due to other diseases (diabetes mellitus, hyperthyroidism, carcinoid tumor, and lymphomas).

The following parameters were collected: age, sex, family history, age/period of onset (birth, childhood, puberty, later) areas primarily affected by hyperhidrosis, and previous therapy.

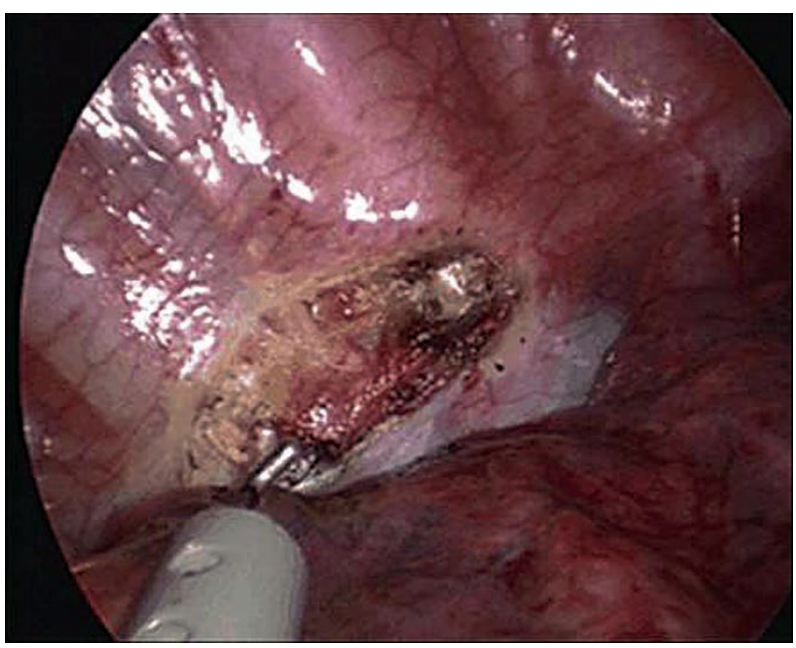

Figure 2. Sympathetic chain

\section{Severity of disease and post-operative effects}

(Quality of Life Questionnaire), were graded using Hyperhidrosis Disease Severity Scale - HDSS (International Hyperhidrosis Society, www.sweathelp. org), between 1 (no symptoms) and 4 (worst symptoms) (Table 1).

Patients were asked to rate their symptoms in different areas before and after the surgery: scores between 3 and 4 indicated severe hyperhidrosis; scores between 1 and 2 indicated mild or moderate hyperhidrosis. After surgery, patients rated their symptoms again: 1-point improvement was associated with a $50 \%$ reduction in sweat production, and

Table 1. Hyperhidrosis Disease Severity Scale (International Hyperhidrosis Society)

How would You rate the severity of your hyperhidrosis symptoms?

$$
1 \quad \begin{aligned}
& \text { My sweating is never noticeable and never interferes with my daily activities } \\
& \text { (quality of life - excellent) }
\end{aligned}
$$

2 My sweating is tolerable, but sometimes interferes with my daily activities (quality of life - good)

3 My sweating is barely tolerable and frequently interferes with my daily activities (quality of life - bad)

$4 \quad$ My sweating is intolerable and always interferes with my daily activities (quality of life - very bad) 
2-point improvement with $80 \%$ reduction in sweat production.

Statistical analysis Data were presented as mean \pm standard deviation for continuous variables, and as frequencies while categoric data were presented percentages. Means were compared by two-sided t-test for dependent samples. Two-sided t-test was used for comparison of percentages too. Chi square test $\left(\mathrm{c}^{2}\right)$ was used to test if obtained frequencies significantly deviated from the expected, e.g. random. Two-tailed p-values less than 0.05 were considered statistically significant. Statistical analysis was performed using JMP statistical software (JMP 7, SAS Institute, Cary, $\mathrm{NC})$.

\section{Results}

A total of 162 patients were evaluated. There were 64 (39.51\%) males and 98 (60.49\%) females, with the mean age $( \pm \mathrm{SD})$ of $30.5( \pm 8.3)$ years. The youngest patient was 16 years old, and the oldest 58 years old.
More than half of all patients with palmaraxillary-plantar hyperhidrosis (57.14\%) and palmarplantar hyperhidrosis $(56.52 \%)$ stated that they had hyperhidrosis since early childhood, whereas $33.33 \%$ of patients with axillary hyperhidrosis and $31.25 \%$ of patients with palmar-axillary hyperhidrosis stated that their disease did not start until puberty (two-sided $\mathrm{p}=0,03$ ). There were no sex-specific differences.

A total of $35.18 \%$ of evaluated patients were able to name at least one member of their family who also suffered from hyperhidrosis.

The most commonly affected areas were: palmaraxillary-plantar, in 49 patients (30.25\%), axillary in 36 patients (22.22\%), palmar-plantar in 23 patients (14.20\%), palmar-axillary in 16 patients $(9.88 \%)$, and palmar in 11 patients $(6.79 \%)$.

There were no significent differences between males and females in regard to localization of the affected areas. However, statistically, females sweat more frequently in the palmar - axillary - plantar sites than men (two-sided $\mathrm{p}=0.06$ ) (Table 2).

Table 2. The most commonly affected areas of the body (\%)

\begin{tabular}{lcccccc} 
Sites & $\begin{array}{r}\text { Male } \\
\mathbf{n}=\mathbf{6 4}\end{array}$ & $\begin{array}{l}\text { (\%) } \\
\text { Axillary (n=36) }\end{array}$ & $\begin{array}{r}\text { Female } \\
\mathbf{n}=\mathbf{9 8}\end{array}$ & $\begin{array}{r}\text { Total } \\
\mathbf{n}=\mathbf{1 6 2}\end{array}$ & $(\%)$ \\
\hline Facial $(\mathrm{n}=7)$ & 5 & 7.81 & 2 & 2.04 & 7 & 4.32 \\
\hline Facial+ axillary $(\mathrm{n}=10)$ & 5 & 7.81 & 5 & 5.10 & 10 & 6.17 \\
\hline Facial + palmar + axillary + plantar $(\mathrm{n}=10)$ & 1 & 1.56 & 9 & 9.18 & 10 & 6.17 \\
\hline Palmar (n=11) & 4 & 6.25 & 7 & 7.14 & 11 & 6.79 \\
\hline Palmar + axillary (n=16) & 8 & 12.5 & 8 & 8.16 & 16 & 9.88 \\
\hline Palmar + axillary + plantar $(\mathrm{n}=49)$ & 14 & 21.87 & 35 & 35.71 & 49 & 30.25 \\
\hline Palmar + plantar (n=23) & 12 & 18.75 & 11 & 11.22 & 23 & 14.20 \\
\hline Total & 64 & 100.0 & 98 & 100 & 162 & 100.0 \\
\hline
\end{tabular}


Previous therapies used by 50 patients $(30.86 \%)$ included ointments/tinctures (11.73\%), botulinum toxin injections (8.02\%), iontophoresis (3.09\%), antiperspirants (2.47\%), drugs - tranquilizers/ sedatives $(1.85 \%)$, urotropin $(1.85 \%)$, acupuncture $(1.23 \%)$, homeopathy $(0.62 \%)$.

Nevertheless, $73.43 \%$ of male and $66.32 \%$ of female patients (two-sided $\mathrm{p}=0.35$ ) received no previous therapy. Statistically, females used ointments/ tinctures more frequently than men (Table 3).

All 162 patients with primary hyperhidrosis, underwent bilateral thoracoscopic sympathectomy. Postoperative mortality and severe morbidity (Horner's syndrome, pneumothorax, and neuralgia) were not registered in this study. The mean hospital stay was $1.28 \pm 0.68$ days.

Before surgery, 148/162 patients $(91.36 \%)$ reported severe sweating (HDSS scores 3 or 4 ) and after surgery, 151/162 patients (93.21\%) reported mild or moderate hyperhidrosis (HDSS scores 1 or 2). The highest mean score was given for the combination of facial-palmar-axillary-plantar hyperhidrosis $(3.80 \pm 0.24)$ and for the combination of facial-axillary hyperhidrosis $(3.70 \pm 0.19)$.

A 2-point improvement in the mean HDSS score after surgery was found in patients with: palmar-axillary-plantar hyperhidrosis (from $3.61 \pm 0.07$ to $1.26 \pm 0.07$ ), facial-plamar-axillaryplantar hyperhidrosis (from $3.80 \pm 0.24$ to $1.40 \pm 0.24$ ) and facial-axillary hyperhidrosis (from $3.70 \pm 0.19$ to $1.70 \pm 0.19$ ).

Sex-specific analysis was not performed, due to a small number of patients in specific groups.

After surgery, $34.57 \%$ of patients reported compesatory sweating on the other parts of their body (lower back, abdomen).

Table 3. Previous conservative therapy (\%)

\begin{tabular}{lcccccc}
\multicolumn{1}{c}{ Previous conservative therapy } & $\begin{array}{c}\text { Male } \\
\mathbf{n}=\mathbf{6 4}\end{array}$ & $\begin{array}{l}\text { (\%) } \\
\text { Ointments/tinctures }\end{array}$ & $\begin{array}{c}\text { Female } \\
\mathbf{n = 9 8}\end{array}$ & $\begin{array}{c}\text { Total } \\
\mathbf{n = 1 6 2}\end{array}$ & (\%) \\
\hline Botulinum toxin injection & 5 & 7.81 & 8 & 8.16 & 13 & 8.02 \\
\hline Iontophoresis & 1 & 1.56 & 4 & 4.08 & 5 & 3.09 \\
\hline Antiperspirants & 1 & 1.56 & 3 & 3.06 & 4 & 2.47 \\
\hline Drugs - tranquilizers/sedatives & 2 & 3.12 & 1 & 1.02 & 3 & 1.85 \\
\hline Urotropin & 2 & 3.12 & 1 & 1.02 & 3 & 1.85 \\
\hline Acupuncture & 0 & 0.0 & 2 & 2.04 & 2 & 1.23 \\
\hline Homeopathy & 0 & 0.0 & 1 & 1.02 & 1 & 0.62 \\
\hline No previous therapy & 47 & 73.43 & 65 & 66.32 & 112 & 69.14 \\
\hline Total & 64 & 100.0 & 98 & 100.0 & 162 & 100.0 \\
\hline
\end{tabular}


Table 4. The mean Hyperhidrosis Disease Severity Scale (HDSS) scores of sweating in different sites before and after surgery

\begin{tabular}{|c|c|c|c|}
\hline $\begin{array}{l}\text { HDSS scores } \\
\text { Site of sweating }\end{array}$ & $\begin{array}{l}\text { Before surgery } \\
\quad(\text { mean } \pm S D)\end{array}$ & $\begin{array}{c}\text { After surgery } \\
(\text { mean } \pm \text { SD })\end{array}$ & P value* \\
\hline Axillary $(\mathrm{n}=36)$ & $3.42 \pm 0.73$ & $1.72 \pm 0.85$ & $\mathrm{p}<0.001$ \\
\hline Facial $(\mathrm{n}=7)$ & $3.29 \pm 0.27$ & $1.85 \pm 0.27$ & $\mathrm{p}<0.003$ \\
\hline Facial + axillary $(\mathrm{n}=10)$ & $3.70 \pm 0.19$ & $1.70 \pm 0.19$ & $\mathrm{p}<0.001$ \\
\hline Facial + palmar + axillary + plantar $(\mathrm{n}=10)$ & $3.80 \pm 0.24$ & $1.40 \pm 0.24$ & $\mathrm{p}<0.001$ \\
\hline Palmar $(\mathrm{n}=11)$ & $3.45 \pm 0.29$ & $1.63 \pm 0.29$ & $\mathrm{p}<0.001$ \\
\hline Palmar + axillary $(\mathrm{n}=16)$ & $3.37 \pm 0.19$ & $1.81 \pm 0.19$ & $\mathrm{p}<0.01$ \\
\hline Palmar + axillary + plantar $(n=49)$ & $3.61 \pm 0.07$ & $1.26 \pm 0.07$ & $\mathrm{p}<0.001$ \\
\hline Palmar + plantar $(n=23)$ & $3.30 \pm 0.70$ & $1.43 \pm 0.66$ & $\mathrm{p}<0.001$ \\
\hline
\end{tabular}

* Due to two-sided t-test for dependent samples

All patients had a six month follow-up period with regular controls. Due to compensatory swaeting on the back and abdomen, only $4.94 \%$ and $1.65 \%$ of patients reported bad or very bad quality of life, respectively. Following surgery, the majority of patients [137/162 (84.56\%)] demonstrated significant improvement in quality of life (Yates corrected $c^{2}(1)=228.42$; $\mathrm{p}=0.0000)$ (Table 5).

\section{Discussion}

Although it is not a major medical problem, primary hyperhidrosis significantly affects the social and psychological aspects of patients' lives, inducing their withdrawal from society (1).

More than a third of all patients affected by hyperhidrosis and included in this study were female patients, which corresponded with previous observations $(3,4,12)$. The average age on presentation was 30 years in both sexes, which was in accordance with other studies $(4,12)$. However, our patients were not able to identify either the precise time of disease onset, nor the precise age of disease onset. That is why we decided to divide their lives into periods (birth, childhood, puberty, later). Axillary hyperhidrosis manifested later than palmar-axillary-plantar. Similar results were obtained by Kariman-Teherani et al (12).

More than a third $(35.18 \%)$ of all evaluated patients in this study reported positive family history, which was in agreement with other studies, where it ranged from $30 \%$ to $65 \%(4,7,13)$.

The most frequent sites of excessive sweating were palmar-axillary-plantar, which was similar with previous observations $(3,4,12)$. In regard to sites of affected areas, there were no significant differences between males and females. A statistical trend was found for females to sweat more frequently in the palmar-axillary-plantar sites, which was opposite to results of Kariman-Teherani et al, where women sweated significantly more frequently in the palmarplantar areas than men, while statistical trends were 
Table 5. Quality of life before and after surgery

\begin{tabular}{ccc} 
Quality of the life & Before surgery (\%) & After surgery (\%) \\
Very good & $0(0 \%)$ & $93(57.41 \%)^{*}$ \\
\hline Good & $14(8.62 \%)$ & $58(35.80 \%)^{*}$ \\
\hline Bad & $53(32.73 \%)^{*}$ & $8(4.94 \%)$ \\
\hline Very bad & $95(58.65 \%)^{*}$ & $3(1.85 \%)$ \\
\hline
\end{tabular}

*Statistically significant (Yates corrected $c^{2}(1)=228.42 ; \mathrm{p}=0.0000$ )

found for armpits in women and palmar-axillaryplantar sites in men (12).

There were 50 patients $(30.86 \%)$ who indicated that they had used one or more therapies prior to surgery. Most frequently used (in $11.73 \%$ of patients) were ointments and tinctures. This was probably due to the fact that ointments and tinctures could be easily obtained and did not require special consultation. Women used these products more frequently than men, which was in accordance with the previous study (12).

Patients included in our study were preselected patients with severe focal primary hyperhidrosis. Since the vast majority of them $(91.36 \%)$ had HDSS scores 3 or 4 , all of them underwent bilateral thoracoscopic sympathectomy. Thus, the objective of this paper was also to review early postoperative results and a 6 -month follow-up of patients undergoing videothoracoscopic sympathectomy. After surgery, $93.21 \%$ of patients reported mild or moderate hyperhidrosis, and $84.56 \%$ reported a significant improvement in quality of life. These data were similar to other studies $(14,15$, 21 ), emphasizing the effectiveness of thoracoscopic sympathectomy in the treatment of primary focal hyperhidrosis.

The first surgical treatment of hyperhidrosis was reported at the end of the $19^{\text {th }}$ and the beginning of the $20^{\text {th }}$ century. After video-assisted thoracoscopic surgery was introduced into the standard thoracic surgery practice in the 90 s of the $20^{\text {th }}$ century, as well as the latest technological advances, thoracoscopic sympathectomy has become the standard treatment for primary hyperhidrosis. Open surgical techniques (posterior, supraclavicular, transthoracic or transaxillary approaches) are nowadays almost completely abandoned. They were substituted by minimally invasive procedures, such as videothoracoscopic sympathectomy or percutaneous radiofrequency ablation $(15,17)$. The advantages of this minimally invasive surgical procedure include: excellent visualization of the sympathetic chain, facilitating the surgical procedure itself, a significant reduction of hospital stay, reduction in analgesic medications, as well as extraordinary postoperative results. According to the literature data, after bilateral thoracoscopic sympathectomy for palmar hyperhidrosis, outstanding therapeutic results have been achieved in over 99\% of cases. Favorable effects are immediately evident, and the patient usually wakes up from anesthesia with dry and warm palms. In cases with facial blushing and facial and axillary hyperhidrosis, successful results were reported in 95\% of cases (18).

There was no postoperative mortality and severe morbidity (Horner's syndrome, pneumothorax, and neuralgia) in any of the 162 patients with primary hyperhidrosis who underwent thoracoscopic sympathectomy. The mean hospital stay was $1.28 \pm 0.68$-days. According to the literature data, complications occur in less than $1 \%$ of cases: Horner's syndrome, unsuccessful sympathectomy due to unresected Kuntz's fibers, pneumothorax, bleeding, 
postoperative neuralgia, esophageal injury $(19,20)$. In most cases complications depend on the surgeon's experience and skills. Thus, careless cutting of the first thoracic ganglion (T1) may result in Horner's syndrome, while unresected Kuntz's fibers, can results in unsuccessful sympathectomy. Recently, it has been reported that symptoms of compensatory sweating may be prevented by keeping the second thoracic ganglion (T2) unresected (21). Clipping has been proposed (in order to replace electrocauter or ultrasound knife), since it may be easily removed in case of excessive compensatory sweating or Horner's syndrome (16).

After surgery, $34.57 \%$ of patients reported compesatory sweating on other parts of the body (lower back, abdomen), but after six months of followup, only $4.94 \%$ and $1.65 \%$ of patients reported bad, or very bad quality of life, respectively. Compensatory sweating is undesirable, but fairly common side effect of sympathetic nerve surgery, and with negative impact on the quality of life after surgery. This phenomenon significantly depends on the environment, such as the air temperature and humidity. About $40 \%$ of patients may also develop a transitory excessive saliva secretion. Although the reported compensatory sweating rate ranges from $30 \%$ to $65 \%(22-24)$, it is mostly a transient, well tolerated side effect, thus the vast majority of patients express high satisfaction with the results of this surgery with respect to alleviation of their primary symptoms $(20,25-27)$.

In conclusion, thoracoscopic sympathectomy is a standard procedure for the treatment of primary focal hyperhidrosis, associated with a high success rate.

\section{References}

1. Milanez de Campos JR, Kauffman P, de Campos Wereba E, Andrade Filho LO, Kusniek S, Wolosker N. Quality of life, before and after thoracic sympathectomy: report on 378 operated patients. Ann Thorac Surg 2003;76:886-91.

2. Wolosker N, Yazbek G, de Campos JR, Munia MA, Kauffman $\mathrm{P}$, Jatene FB, et al. Quality of life before surgery is predictive factor for satisfaction among patients undergoing sympathectomy to treat hyperhidrosis. J Vasc Surg. 2010;51:1190-4.

3. Strutton RD, Kowalsky JW, Glaser DA, Stang PE. US prevalence of hyperhidrosis and impact on individuals with axillary hyperhidrosis: results from national survey. J Am Acad Dermatol 2004;51:241-8.

4. Lear W, Kessler E, Solish N. An epidemiological study of hyperhidrosis. Dermatol Surg 2007;33:69-75.

5. Doolabh N, Horswell S, Wiliams M, Huber L, Prince S,
Meyer DM. Thoracoscopic sympathectomy for hyperhidrosis: indications and results. Ann Thorac Surg 2004;77:410-4.

6. Hund M, Kinkelin I, Naumann M, Hamm H. Definition of axillary hyperhidrosis by gravimetric assessment. Arch Dermatol 2002;138:539-41.

7. Ro KM, Cantor RM, Lange KL, Ahn SS. Palmar hyperhidrosis: evidence of genetic transmision. J Vasc Surg 2002;35:382-6.

8. Flanagan KH, King R, Glaser DA. Botulinum toxin typa A versus topical $20 \%$ aluminium chloride for the treatment of moderate to severe primary focal axillary hyperhidrosis. J Drugs Dermatol 2008;7:221-7.

9. Moreno-Lorenzo C, Castro-Sanches AM, Guisado-Barrilao R, Linares-Solano J, Ruiz-Villaverde R, Villaverde-Gutierrez C. Dermatologic iontophoresis in palmar hyperhidrosis: immunohistochemical study. Eur J Dermatol 2010;20:235-6.

10. Grunfeld A, Murray CA, Solish N. Botulinum toxin for hyperhidrosis: a review. Am J Clin Dermatol 2009;10:87-102.

11. Gregoriou S, Rigopoulos D, Makris M, Liakou A, Agiosofitou E, Stefaneki C, et al. Effects of botulinum toxin A therapy for palmar hyperhidrosis in plantar sweat production. Dermatol Surg 2010;36:496-8.

12. Karimian-Teherani D, Panhofer P, Ringhofer C, Jakesz R, Prager M, Zacherl J, et al. New epidemiological aspects of patients with severe hyperhidrosis presenting for sympathetic surgery. J Eur Acad Dermatol Venerol 2009;23:651-5.

13. Hamm H, Naumann MK, Kowalsky JW, Kutt S, Kozma C, Teale C. Primary focal hyperhidrosis: disease characteristics and functional impairment. Dermatology 2006;212:343-53.

14. Assalia A, Bahouth H, Ilivitzki A, Assi Z, Hashmonai M, Krausz MM. Thoracoscopic sympathectomy for primary palmar hyperhidrosis: resection versus transection: a prospective trial. World J Surg 2007;31:1976-9.

15. Murphy MO, Ghosh J, Khwaja N, Murray D, Halka TA, Carter A, et al. Upper dorsal endoscopic thoracic sympathectomy: a comparision of one- and two-port ablation techniques. Eur J Cardiothorac Surg 2006;30:223-7.

16. Lin CC, Mo LR, Lee SM, Ng SM, Hwang MH. Thoracoscopic T2-sympathectomy block by clipping: a better and reversible operation for treatment of hyperhidrosis palmaris. Experience in 326 cases. Eur J Surg 1998;64:13-6.

17. Georghiou GP, Berman M, Bobovnikov V, Vidne BA, Saute M. Minimally invasive thoracoscopic sympathectomy for palmar hyperhidrosis via a transaxillary single-port approach. Interact Cardiovasc Thorac Surg 2004;3:437-41.

18. Dumont P, Denoyer A, Robin P. Long term results of thoracoscopic sympathectomy for hyperhidrosis. Ann Thorac Surg 2004;78:1801-7.

19. Chang YT, Li HP, Lee JY, Lin PJ, Lin CC, Kao EL, et al. Treatment of palmar hyperhidrosis: T(4) level compared with T(3) and T(2). Ann Surg 2007;246:330-6.

20. Dewey TM, Herbert MA, Hill SL, Prince SL, Mack MJ. One-year follow-up after thoracoscopic sympathectomy for hyperhidrosis: outcomes and consequences. Ann Thorac Surg 2006;81:1227-32.

21. Van't Riet M, de Smet A, Huiken A, Kazemier G, Bonjer H. Prevention of compensatory hyperhidrosis after thoracoscopic sympathectomy for hyperhidrosis. Surg Endosc 2001;15:1159-62. 
22. Rodrigez PM, Freixinet JL, Husein M, Valencia JM, Gil RM, Herrero J, et al. Side effects, complications and outcome of thoracoscopic sympathectomy for palmar and axillar hyperhidrosis in 406 patients. Eur J Cardiothorac Surg 2008;34:514-9.

23. Schmidt J, Bechara FG, Altmeyer P, Zirngibl H. Endoscopic thoracic sympathectomy for severe hyperhidrosis: impact of restrictive denervation on compensatory sweating. Ann Thorac Surg 2006;81:1048-55.

24. Wait SD, Killory BD, Lekovic BD, Ponce FA, Kenny KJ, Dickman CA. Thoracoscopic sympathectomy for hyperhidrosis: analysis of 642 procedures with special attention to Horners syndrom and compensatory hyperhidrosis. Neurosurgery 2010;19:526-31.

25. Jeganathan R, Jordan S, Jones M, Grant S, Diamond O, McManus $\mathrm{K}$, et al. Bilateral thoracoscopic sympathectomy: results and long term follow up. Interact Cardiovasc Thorac Surg 2008;7:67-70.

26. Krasna MJ. Thoracoscopic sympathectomy: a standardized approach to therapy for hyperhidrosis. Ann Thorac Surg 2008;85:764-7.

27. Bachmann K, Standl N, Kaifi J, Busch P, Winkler E, Mann $\mathrm{O}$, et al. Thoracoscopic sympathectomy for palmar and axillar hyperhidrosis: four year outcome and quality of life after bilateral 5-mm dual port approach. Surg Endosc 2009;23:1587-93.

\section{Videotorakoskopska simpatektomija - standarna hirurška metoda za lečenje primarne hiperhidroze na Klinici za grudnu hirurgiju u Sremskoj Kamenici}

\section{Sažetak}

Uvod: Primarna hiperhidroza prisutna je kod približno $3 \%$ svetske populacije. Definiše se kao prekomerno i nekontrolisano znojenje dlanova, pazušnih jama i lica. Konzervativna terapija obuhvata uporebu raznih antiperspiranata, lekova, jontoforeze, injekcije botulinum toksina tip A (botoks) ali je hirurška terapija jedina pokazala najbolje trajne rezultate.

Cilj: Ispitivanje je imalo za cilj da prikaže neke epidemiološke karakteristike pacijenata sa primarnom fokalnom hiperhidrozom i terapijske efekte torakoskopske simpatektomije.

Materijal i metode: Ispitivanje je obuhvatilo 162 osobe kod kojih je urađena torakoskopska simpatektomija zbog primarne fokalne hiperhidroze na Klinici za grudnu hirurgiju Instituta za plućne bolesti Vojvodine u Sremskoj Kamenici, u periodu između januara 2008. i decembra 2009. godine. Popunjavanjem upitnika (International Hyperhidosis Society, www.sweathelp.org), pre i posle operacije, pacijenti su ocenili stepen svojih tegoba na zahvaćenim delovima tela HDSS - Hyperhidrosis Disease Severity Scale skorom 1 do 4 (eng. skala za ocenu težine hiperhidroze). Sve operacije su izvedene u lateralnom dekubitusu, pomoću dvolumenskog endotrahelanog tubusa, putem dve petomilimetarske radne porte, uz videotorakoskopsku kameru i endoskopsku ultrazvučnu kuku, presecanjem simpatičkog lanca između drugog (T2) i trećeg torakalnog gangliona (T3) i ekstirpacijom simpatičkog lanca između trećeg i četvrtog torakalnog gangliona (T3-T4). Ekstirpirani materijal je poslat na ex tempore patohistološku verifikaciju. Ultrazvučnim makazama vršena je lateralna resekcija parijetalne pleure po telima drugog i trećeg rebra počev od kostovertebralnog ugla, u dužini od $4-5 \mathrm{~cm}$, čime se omogućilo presecanje Kuntzovih nerava (koji premošćuju drugi i treći grudni ganglion).

Rezultati: U istraživanje je uključeno 64 (39,51\%) osoba muškog pola i 98 (60,49\%) osoba ženskog pola, prosečne starosti (u momentu kada su se javili na operaciju) $30,5 \pm 8,3$ godina. $S$ obzirom da pacijenti nisu mogli da navedu tačnu godinu života u kojoj je bolest počela, mi smo početak bolesti vezali za pojedine faze života (rođenje, detinjstvo, pubertet, kasniji period života) za koje smo mogli dobiti podatke. Tako je više od polovine $(57,14 \%)$ pacijenata sa palmarnomaksilarnom-plantarnom hiperhidrozom i palmarnomplantarnom hiperhidrozom $(56,52 \%)$ tvrdilo da je njihova bolest započela u ranom detinjstvu, dok je $33,33 \%$ svih pacijenata sa aksilarnom hiperhidrozom i $31,25 \%$ pacijenata sa palmarnom-aksilarnom hiperhidrozom tvrdilo da njihova bolest nije počela pre puberteta (two-saided $\mathrm{p}=0,03$ ). Obolele srodnike je navelo $35,18 \%$ pacijenata. Najčešće lokalizacije zahvaćene prekomernim znojenjem bile su: palmarno-aksilarno-plantarna (30,25\%), aksilarna $(22,22 \%)$ i palmarno-plantarna $14,20 \%$. Pedeset pacijenata $(30,86 \%)$ je pre operacije koristilo neku 
konzervativnu terapiju. Najčešće korišćene terapije bile se: različite kreme $(11,73 \%)$, botoks injekcije $(8,02 \%)$ i jontoforeza (2,47\%). Pre operacije, 148/162 obolelih $(91,36 \%)$ ocenilo je svoje znojenje teškim (HDSS skor 3-4). Sve operacije su izvedene uspešno bez komplikacija i perioperativnog morbiditeta. Prosečno trajanje hospitalizacije iznosilo je 1,28+0,68 dana. Posle operacije 151/162 obolelih $(93,21 \%)$ ocenilo je svoje znojenje kao blago ili umereno (HDSS skor 1-2). Nakon operacije kod $34,57 \%$ pacijenata javilo se prolazno kompenzatorno znojenje (donji deo leđa i stomak).
Svi pacijenti su praćeni tokom šest meseci. Samo $4,94 \%$ operisanih pacijenata imalo je loš a $1,85 \%$ veoma loš kvalitet života usled kompenzatornog znojenja u predelu donjeg dela leđa i trbuha, dok je $84,56 \%$ imalo značajno poboljšanje kvaliteta života $\mathrm{u}$ odnosu na period pre operacije (Yates corrected $\mathrm{c}^{2}$ $(1)=228,42 ; \mathrm{p}=0,0000)$.

Zaključak: Videotorakoskopska simpatektomija predstavlja standardnu metodu u lečenju obolelih od primarne hiperhidroze, koja pruža visok stepen bezbednosti i efikasnosti.

\section{Ključne reči}

Hiperhidroza; Simpatektomija; Video-asistirana torakalna hirurgija 